\title{
Influence of Nitrogen Sources and Application Methods on Growth and Yield of Soybean [Glycine max (L.) Merrill]
}

\author{
I. Bala Manikanta*, Jamkhogin Lhungdim, K. Nandini Devi, \\ N. Surbala Devi and N. Gopimohan Singh
}

College of Agriculture, Central Agricultural University, Imphal 795004, India

*Corresponding author

\section{Keywords}

Nitrogen sources, Soil incorporation, Band placement, Growth and yield

\section{Article Info}

\section{Accepted:}

07 September 2020

Available Online:

10 October 2020

\section{A B S T R A C T}

A field experiment was conducted during the kharif season of 2019 in the research farm of college of Agriculture, Central Agricultural University, Imphal to study the Influence of Nitrogen Sources and Application Methods on Growth and Yield of soybean \{ Glycine max (L.) Merrill $\}$. The treatments comprised of four Nitrogen sources [N1 $(75 \% \mathrm{~N}$ Urea $+25 \% \mathrm{~N}$ FYM), N2(75\% N Urea $+25 \% \mathrm{~N}$ poultry manure), $\mathrm{N} 3(75 \% \mathrm{~N}$ Urea $+25 \% \mathrm{~N}$ Vermi compost), and $\mathrm{N} 4(100 \% \mathrm{~N}$ Urea)] and two Application methods[M1(Soil incorporation), M2(Band placement)] Which were laid out in Factorial Randomized Design (FRBD) with eight treatment combinations and replicated thrice. Among Nitrogen sources all growth parameters, yield attributes and yield were performed well under $\mathrm{N} 2(75 \% \mathrm{~N}$ Urea $+25 \% \mathrm{~N}$ Poultry manure) followed by $\mathrm{N} 3(75 \% \mathrm{~N}$ Urea $+25 \% \mathrm{~N}$ Vermi compost). While lowest values were found under $\mathrm{N} 1(75 \% \mathrm{~N}$ Urea $+25 \% \mathrm{~N}$ FYM $)$. Between two application methods M2 (Band placement) performed better. Among various growth parameters plant height, number of branches/plant, dry matter accumulation/plant were noticed maximum with the $75 \% \mathrm{~N}$ Urea+25\% N Poultry manure applied in band placement method $\left(\mathrm{N}_{2} \mathrm{M}_{2}\right)$. Similarly, Number of pods/plant, grain yield $(\mathrm{q} / \mathrm{ha})$, straw yield $(\mathrm{q} / \mathrm{ha})$ and harvest index $(\%)$ were noticed maximum with same treatment combination $\mathrm{N}_{2} \mathrm{M}_{2}$. Similarly gross returns and net returns was found best in $\mathrm{N}_{2} \mathrm{M}_{2}$.

\section{Introduction}

Soybean [Glycine $\max (\mathrm{L})$ Merrill] is known as the "GOLDEN BEAN" of the 20th Century. It can be treated as oilseed as well as pulse crop with the highest percentage (40$45 \%$ ) of protein among all pulses. It is the only pulse crop that contains $20 \%$ of oil in the seed. That's why soybean is also regarded as potential oil yielding crop. It contributes $1 / 3$ rd of total oil produced in the world. Soybean posses a high nutritional quality protein, which is rich in valuable amino acid lycine (5\%). Soybean being the richest, cheapest and easiest source of best quality proteins and fats and having a vast multiplicity of uses as food and industrial products is sometimes called a Wonderer.

At present soybean yields are realised below its potential yielding capacity. The main reasons for not realising its full yielding potentiality, are lack of use of proper nutrition mainly nitrogen and its application methods. 
For getting higher yield, it is necessary to optimize the nutrients inputs. Soybean, being a leguminous crop, is capable to fix atmospheric nitrogen through symbiosis. However, several studies have shown that the symbiotic $\mathrm{N}$-fixation is not able to meet high N-requirement of this crop particularly under $\mathrm{N}$-deficient conditions. The nitrogen requirement of soybean is high because of high yield potential and high protein content in grain (40-45\%). Initial application of nitrogen doses stimulates root development, nodulation, good growth and yield. Starternitrogen application is directed at providing soybean with readily available soil nitrogen during seedling development and has been shown to increase soybean grain yields (Touchton and Rickerl, 1986). Atmospheric nitrogen fixed by Bradyrhizobium japonicum in nodules and mineral nitrogen are both sources of nitrogen for developing soybean plant with fixation capacity of $70 \%$ of the total nitrogen uptake. Amount of nitrogen fixed by soybean varies from 70 to $120 \mathrm{~kg} / \mathrm{ha}$ (Tisdale and Nelson, 1975). Nitrogen application also improves the growth of the soybean plants. It has been reported that leaf area index (LAI) has been reported to increase with increase in nitrogen application (Grewal et al., 1994).

Nitrogen is mainly applied to soil as broad casting method. Soil application of nitrogen as broadcasting often results in lower efficiency of concerned nutrients. The broad casted nitrogen undergoes several changes and losses which occur through leaching and

\section{Materials and Methods}

The investigation was carried out at research farm of College of Agriculture, Central Agricultural University, Imphal during kharif season of 2019. The experimental site was located at 24\% $46^{\prime} \mathrm{N}$ latitude and 93 ${ }^{\circ} 54^{\prime} \mathrm{E}$ longitude at an altitude of $775 \mathrm{~m}$ above, the mean sea level. It comes under the Eastern
Himalayan Region (II) and subtropical zone (NEH-4) of Manipur. The climatic condition of Imphal valley is sub-tropical. The rainy season usually begins by May and extends up to September. The average annual rainfall of Imphal valley is $1212 \mathrm{~mm}$ and the winter normally begins from mid November and extends up to the end of February. The amount of rainfall received during the crop period was $738 \mathrm{~mm}$. The soil of the experimental site was clay in texture with medium fertility status and acidic in reaction with a soil $\mathrm{pH}$ of 5.39. The chemical composition of the soil indicated that the soil was low in available nitrogen $(181.8 \mathrm{~kg} / \mathrm{ha})$, medium in available phosphorus $(22.3 \mathrm{~kg} / \mathrm{ha})$, medium in available potassium $(227.4 \mathrm{~kg} / \mathrm{ha})$ and high in organic carbon content (1.2\%).

The experiment consist of treatment combination of four types of Nitrogen sources $(75 \% \mathrm{~N} \quad$ Urea $+25 \% \mathrm{~N} \quad \mathrm{FYM}, \quad 75 \% \mathrm{~N}$ Urea $+25 \% \mathrm{~N}$ Poultry manure, $75 \% \mathrm{~N}$ Urea+25\%N Vermi compost, 100\% N Urea) and two types of application methods( Soil incorporation, Band placement) Which were laid out in Factorial Randomized Block Design(FRBD) with eight treatment combinations and replicated thrice. Soybean variety Dsb-19 was sown @ 80 kg seed ha ${ }^{-1}$ in rows $45 \mathrm{~cm}$. The recommended dose of fertilizer $\mathrm{N}: \mathrm{P}_{2} \mathrm{O}_{5}: \mathrm{K}_{2} \mathrm{O}$ was applied @ 20:40:30 kg ha ${ }^{-1}$ for soybean crop. phosphorus and potassium was applied as basal through chemical fertilizers SSP and muriate of potash but Nitrogen was applied through inorganic (Urea) and organic (FYM, Poultry manure and Vermincompost) based on treatments. The nitrogen composition in organic manures is FYM $(0.42 \%)$, Poultry manure $(1.83 \%)$, vermin compost $(1.55 \%)$.

The biometric observations were recorded on growth characters like plant height and number of branches per plant on five sample plants selected randomly from each net plot. For dry matter studies three plant samples 
were uprooted from each gross plot. Postharvest studies include the seed yield ( $\mathrm{kg} / \mathrm{ha})$, stover yield (kg/ha) and harvest index (\%) were also recorded from each net plot at the time of harvest. All the data obtained were statistically analysed by the method of analysis of variance to test the significance of the treatment effects as well as result interpretation as given by Gomez and Gomez (1984). F-test at 5\% level of probability was used to test the significance of treatment effect and wherever the "F" test was significant critical difference (CD) values were given at $5 \%$ level of significance.

\section{Results and Discussion}

\section{Effect of nitrogen sources and application methods on growth characters of soybean}

Data concerning the plant height, number of branches per plant and dry matter accumulation per plant as influenced by Nitrogen sources and application methods are presented in table 1 .

The data on plant height of soybean recorded at harvest stage reveals that nitrogen sources and application methods bring significant difference among different treatments among nitrogen sources $\mathrm{N} 2(75 \% \mathrm{~N}$ Urea+25\%N Poultry manure) produced tallest plant $(87.06 \mathrm{~cm})$, which was followed by $\mathrm{N} 4$ $(85.55 \mathrm{~cm})$. It might be due to higher amount of Nitrogen availability resulted into more activities of meristematic tissues of the plant, increase in number and size of cell, which results into increased plant height. The results are in conformity with the findings of Shaheen et al., (2017). Among application methods $\mathrm{M}_{2}$ (Band placement) produced maximum plant height $(88 \mathrm{~cm})$. It might be due to improved nutrient use efficiency. The results are conformity with findings of Nettles (1940), Harmoney and Thompson (2005). Among different treatment combinations, maximum plant height was noted with the treatment combination $\mathrm{N} 2 \mathrm{M} 2 \quad(91.56 \mathrm{~cm})$ which might be due to best combination of nitrogen source with application method followed by N4M2 $(87.6 \mathrm{~cm})$. While the least plant height was found in treatment combination $\mathrm{N}_{1} \mathrm{M}_{1}(82.8 \mathrm{~cm})$. The observation on number of branches/plant reveals that the maximum number of branches/plan $\mathrm{t}(17.49)$ was observed in $\mathrm{N} 2(75 \% \mathrm{~N}$ Urea $+25 \% \mathrm{~N}$ Poultry manure) and it was par with $\mathrm{N}_{3}(16.82) \& \mathrm{~N}_{4}(17.19)$ treatments. Where as lowest number of branches/plant (16.18) was observed in $\mathrm{N}_{1} \quad(75 \% \mathrm{~N}$ Urea+25\%N FYM).Among application methods $\mathrm{M}_{2}$ (17.8) gave more number of branches/plant than M1(16.04). Among treatment combination, the maximum number of branches/plant was observed in $\mathrm{N}_{2} \mathrm{M}_{2}$ (18.92) and it was par with $\mathrm{N}_{3} \mathrm{M}_{2}$ (17.24) \& $\mathrm{N}_{4} \mathrm{M}_{2}$ (18.47) and least one was found in $\mathrm{N}_{1} \mathrm{M}_{1}$.

The maximum dry matter accumulation/plant $(65.33 \mathrm{gm})$ was observed in $\mathrm{N}_{2} \quad(75 \% \mathrm{~N}$ Urea $+25 \% \mathrm{~N}$ Poultry manure) and it was par with $\mathrm{N}_{3}(61.26 \mathrm{gm})$. It might be result of increase in photosynthetic activity and accumulation of more photosynthates which might be due to more nutrient availability. whereas lowest drymatter accumulation/plant $(58.73 \mathrm{gm})$ in $\mathrm{N} 1(75 \% \mathrm{~N}$ Urea+25\%N FYM). The results are conformity with the findings of Shaheen et al., (2017). Among application methods maximum dry matter accumulation/plant $(66.81 \mathrm{gm})$ was in $\mathrm{M}_{2}$ (Band placement) than $\mathrm{M}_{1}(55.88 \mathrm{gm})$. Among treatment combination, the maximum drymatter accumulation/plant was observed in $\mathrm{N}_{2} \mathrm{M}_{2}(73.86 \mathrm{gm})$ followed by $\mathrm{N}_{3} \mathrm{M}_{2}$ (64.4gm) and the least one was observed in N1M1 $(52.20 \mathrm{gm})$. Effect of Nitrogen sources and Application methods on yield and yield attributes of soybean: Data concerning the number of pods/plant, grain yield, stover yield and harvest index as influenced by Nitrogen sources and application methods are presented in table 2. 
Treatment details

\begin{tabular}{|c|c|}
\hline Nitrogen sources & Notation \\
\hline 1.75\% Urea+25\% N FYM & $\mathbf{N}_{1}$ \\
\hline 2.75\% Urea+25\% N Poultry manure & $\mathbf{N}_{2}$ \\
\hline $\mathbf{3 . 7 5 \%}$ N Urea+25\% N Vermicompost & $\mathbf{N}_{3}$ \\
\hline $\mathbf{4 . 1 0 0 \%}$ N Urea & $\mathbf{N}_{4}$ \\
\hline Application methods & \\
\hline 1. Soil incorporation & $\mathbf{M}_{1}$ \\
\hline 2. Band placement & $\mathbf{M}_{2}$ \\
\hline
\end{tabular}

Table.1 Effect of nitrogen sources and application methods on growth characters of soybean

\begin{tabular}{|c|c|c|c|}
\hline Treatment & $\begin{array}{l}\text { Plant } \\
\text { height } \\
(\mathbf{c m})\end{array}$ & $\begin{array}{c}\text { Number of } \\
\text { branches } \\
\text { per plant }\end{array}$ & $\begin{array}{c}\text { Dry matter } \\
\text { accumulation per } \\
\text { plant (gm) }\end{array}$ \\
\hline \multicolumn{4}{|c|}{ Nitrogen sources } \\
\hline $\mathrm{N}_{1}(75 \% \mathrm{~N}$ Urea+25\% N FYM) & 85.00 & 16.18 & 58.73 \\
\hline $\mathrm{N}_{2}(75 \% \mathrm{~N}$ urea $+25 \% \mathrm{~N}$ poultry manure $)$ & 87.06 & 17.49 & 65.33 \\
\hline $\mathrm{N}_{3}(75 \% \mathrm{~N}$ urea $+25 \% \mathrm{~N}$ vermi compost $)$ & 84.80 & 16.82 & 61.26 \\
\hline $\mathrm{N}_{4}(100 \% \mathrm{~N}$ urea $)$ & 85.55 & 17.19 & 60.06 \\
\hline S.E. \pm & 0.718 & 0.425 & 1.955 \\
\hline CD at $5 \%$ & 1.544 & 0.914 & 4.204 \\
\hline \multicolumn{4}{|c|}{ Application methods } \\
\hline M1(Soil incorporation) & 83.20 & 16.04 & 55.88 \\
\hline$M_{2}$ (Band placement) & 88.00 & 17.80 & 66.81 \\
\hline S.E. \pm & 0.507 & 0.300 & 1.382 \\
\hline CD at $5 \%$ & 1.091 & 0.646 & 2.973 \\
\hline \multicolumn{4}{|c|}{ Interaction effect } \\
\hline $\mathbf{N}_{1} \mathbf{M}_{1}$ & 82.80 & 15.79 & 52.20 \\
\hline $\mathbf{N}_{1} \mathbf{M}_{2}$ & 87.20 & 16.57 & 65.26 \\
\hline $\mathbf{N}_{2} \mathbf{M}_{1}$ & 82.56 & 16.06 & 56.80 \\
\hline $\mathbf{N}_{2} \mathbf{M}_{2}$ & 91.56 & 18.92 & 73.86 \\
\hline $\mathbf{N}_{3} M_{1}$ & 83.96 & 16.40 & 58.13 \\
\hline $\mathbf{N}_{3} \mathbf{M}_{2}$ & 85.63 & 17.24 & 64.40 \\
\hline $\mathbf{N}_{4} \mathbf{M}_{1}$ & 83.50 & 15.92 & 56.40 \\
\hline $\mathbf{N}_{4} \mathbf{M}_{2}$ & 87.60 & 18.47 & 63.73 \\
\hline S.E. \pm & 1.015 & 0.601 & 2.765 \\
\hline CD at $5 \%$ & 2.183 & 1.293 & 5.946 \\
\hline
\end{tabular}


Table.2 Effect of nitrogen sources and application methods on yield and yield attributes of soybean

\begin{tabular}{|c|c|c|c|c|}
\hline Treatment & $\begin{array}{c}\text { No. of } \\
\text { pods/plant }\end{array}$ & $\begin{array}{c}\text { Grain } \\
\text { Yield } \\
\text { (Q/ha) }\end{array}$ & $\begin{array}{l}\quad \text { Straw } \\
\text { Yield } \\
\text { (Q/ha) }\end{array}$ & $\begin{array}{c}\text { Harvest } \\
\text { Index } \\
(\%)\end{array}$ \\
\hline \multicolumn{5}{|c|}{ Nitrogen sources } \\
\hline N1(75\% N Urea+25\% N FYM) & 106.71 & 23.51 & 32.10 & 42.33 \\
\hline $\begin{array}{c}\mathrm{N} 2(75 \% \mathrm{~N} \text { urea }+25 \% \mathrm{~N} \text { poultry } \\
\text { manure })\end{array}$ & 115.57 & 25.60 & 32.13 & 44.30 \\
\hline $\begin{array}{c}\mathrm{N} 3(75 \% \mathrm{~N} \text { urea+25\% } \mathrm{N} \text { vermi } \\
\text { compost })\end{array}$ & 113.75 & 24.87 & 31.25 & 44.28 \\
\hline N4(100\% N urea) & 107.57 & 24.20 & 31.29 & 43.55 \\
\hline S.E. \pm & 1.616 & 0.335 & 0.332 & 0.295 \\
\hline CD at $5 \%$ & 3.475 & 0.721 & 0.714 & 0.636 \\
\hline \multicolumn{5}{|c|}{ Application methods } \\
\hline M1(Soil incorporation) & 106.16 & 23.42 & 30.65 & 43.31 \\
\hline M2(Band placement) & 115.64 & 25.67 & 32.73 & 43.92 \\
\hline S.E. \pm & 1.143 & 0.237 & 0.234 & 0.209 \\
\hline CD at $5 \%$ & 2.457 & 0.509 & 0.505 & 0.449 \\
\hline \multicolumn{5}{|c|}{ Interaction effect } \\
\hline $\mathbf{N}_{1} \mathbf{M}_{1}$ & 103.65 & 23.00 & 31.55 & 42.25 \\
\hline $\mathbf{N}_{1} \mathbf{M}_{2}$ & 109.77 & 24.03 & 32.65 & 42.40 \\
\hline $\mathbf{N}_{2} \mathbf{M}_{1}$ & 110.79 & 24.10 & 31.29 & 43.50 \\
\hline $\mathbf{N}_{2} \mathbf{M}_{2}$ & 120.36 & 27.10 & 32.97 & 45.10 \\
\hline $\mathbf{N}_{3} \mathbf{M}_{1}$ & 106.00 & 23.50 & 30.05 & 43.87 \\
\hline $\mathbf{N}_{3} \mathbf{M}_{2}$ & 121.50 & 26.24 & 32.45 & 44.70 \\
\hline $\mathbf{N}_{4} \mathbf{M}_{1}$ & 104.21 & 23.09 & 29.72 & 43.61 \\
\hline $\mathbf{N}_{4} \mathbf{M}_{2}$ & 110.93 & 25.31 & 32.85 & 43.50 \\
\hline S.E. \pm & 2.286 & 0.474 & 0.461 & 0.418 \\
\hline CD at $5 \%$ & 4.915 & 1.019 & 1.102 & 0.899 \\
\hline
\end{tabular}

Table.3 Effect of nitrogen sources and application methods on economics of soybean

\begin{tabular}{|c|c|c|c|}
\hline Treatment & $\begin{array}{c}\text { GROSS } \\
\text { RETURNS(₹/ha) }\end{array}$ & $\begin{array}{c}\text { NET } \\
\text { RETURNS(₹/ha) }\end{array}$ & B:C \\
\hline $\mathbf{N}_{\mathbf{1}} \mathbf{M}_{\mathbf{1}}$ & 103500.8 & 55797.8 & 1.16 \\
\hline $\mathbf{N}_{\mathbf{1}} \mathbf{M}_{\mathbf{2}}$ & 108165.2 & 59802.2 & 1.23 \\
\hline $\mathbf{N}_{\mathbf{2}} \mathbf{M}_{\mathbf{1}}$ & 108450.1 & 63544.1 & 1.41 \\
\hline $\mathbf{N}_{\mathbf{2}} \mathbf{M}_{\mathbf{2}}$ & 121950.6 & 76384.6 & 1.67 \\
\hline $\mathbf{N}_{\mathbf{3}} \mathbf{M}_{\mathbf{1}}$ & 105750.7 & 59286.7 & 1.27 \\
\hline $\mathbf{N}_{\mathbf{3}} \mathbf{M}_{\mathbf{2}}$ & 118080.5 & 70956.5 & 1.50 \\
\hline $\mathbf{N}_{\mathbf{4}} \mathbf{M}_{\mathbf{1}}$ & 103920.4 & 60620.4 & 1.40 \\
\hline $\mathbf{N}_{\mathbf{4}} \mathbf{M}_{\mathbf{2}}$ & 113895.7 & 69935.7 & 1.59 \\
\hline
\end{tabular}


The number of pods/plant was significantly affected by different treatments of nitrogen sources. Among nitrogen sources $\mathrm{N}_{2}(115.57)$ gave more number of pods per plant and it was par with $\mathrm{N}_{3}(113.75)$ and least was observed in $\mathrm{N}_{1}(106.71)$. The results are in conformity with Azam Shah et al., (2012). Again application methods $\mathrm{M}_{2}(115.64)$ produced more number of pods per plant than $\mathrm{M}_{1}$ (106.16) the results is in conformity with Timmons et al. (1973). Among treatment combination $\mathrm{N}_{2} \mathrm{M}_{2} \quad$ (120.36) produced significantly maximum number of pods per plant and it was par with $\mathrm{N}_{3} \mathrm{M}_{2}(121.50)$. The less number of pods per plant was observed in $\mathrm{N}_{1} \mathrm{M}_{1}(103.65)$.

The grain yield was found higher in $\mathrm{N}_{2}(25.60$ $\mathrm{Q} / \mathrm{ha})$ followed by $\mathrm{N}_{3}(24.87 \mathrm{Q} / \mathrm{ha})$ and least was observed in $\mathrm{N}_{1}(23.5 \mathrm{Q} / \mathrm{ha})$. Higher grain yield may be due to effect of yield attributing characters. The results is in conformity with Azam Shah et al.(2012), Mamia et al.(2018), Almaz et al. (2017).Again application methods $\mathrm{M}_{2}$ (25.67q/ha)produced superior grain yield than $\mathrm{M}_{1} .(23.42 \mathrm{q} / \mathrm{ha})$ The results is in conformity with Shahzad et al.(2003), Din et al. (1999). Among treatment combination $\mathrm{N}_{2} \mathrm{M}_{2} \quad(27.10 \mathrm{Q} / \mathrm{ha})$ produced significantly highest grain yield and it was par with $\mathrm{N}_{3} \mathrm{M}_{2}$ (26.24q/ha). The lowest grain yield was found in $\mathrm{N}_{1} \mathrm{M}_{1}(23.00 \mathrm{q} / \mathrm{ha})$

Among Nitrogen sources $\mathrm{N}_{2}(32.13 \mathrm{q} / \mathrm{ha})$ ) produced significantly highest stover yield followed by $\mathrm{N}_{4}$ and lowest straw yield was observed in N3. Higher stover production might be due to enhanced vegetative growth. The results is in conformity with Azam Shah et al.(2012), Shaheen et al. (2017).Among application methods $\mathrm{M}_{2}(32.73 \mathrm{q} / \mathrm{ha})$ produced significantly superior stover yield than M1(30.65q/ha). Precisely $\mathrm{N}_{2} \mathrm{M}_{2}$ (32.97q/ha) produced significantly highest stover yield and it was par with $\mathrm{N}_{3} \mathrm{M}_{2}(32.85 \mathrm{q} / \mathrm{ha}) \& \mathrm{~N}_{4} \mathrm{M}_{2}$ $(32.45 \mathrm{q} / \mathrm{ha})$. The lowest straw yield was found to be produced in $\mathrm{N}_{1} \mathrm{M}_{1}(31.55 \mathrm{q} / \mathrm{ha})$. The harvest index was maximum for $\mathrm{N}_{2}(44.30 \%)$. It may be due to higher dry matter partitioning of photosynthates between grain and stover of plant. This is followed by $\mathrm{N}_{3} \quad(44.28 \%)$ and lowest was found in $\mathrm{N}_{1}(42.33 \%)$. Again it can be marked that $\mathrm{M}_{2}(43.92 \%)$ gave higher harvest index than $\mathrm{M}_{1}(43.32 \%)$. Among treatment combination $\mathrm{N}_{2} \mathrm{M}_{2} \quad(45.10 \%)$ produced significantly highest harvest index and it was par with $\mathrm{N}_{3} \mathrm{M}_{2}(44.70 \%)$. The lowest harvest index was found in $\mathrm{N}_{1} \mathrm{M}_{1}(42.25 \%)$.

\section{Economics}

The influence of nitrogen sources and application methods was estimated in terms of economics is presented in Table 3. Among various treatments the highest gross returns ( $₹$ 121950.6/ha) and net returns (₹ 76384.6) was found best in $\mathrm{N}_{2} \mathrm{M}_{2}(75 \% \mathrm{~N}$ Urea+25\%N Poultry manure applied in band placement) and benefit cost ratio(1.67) was recorded significantly higher in same treatment whereas lowest gross return (₹ 103500.8), net returns (₹ 55797.8) and benefit cost ratio (1.16) was observed in treatment $\mathrm{N}_{1} \mathrm{M}_{1}(75 \% \mathrm{~N}$ Urea+25\% N FYM applied in soil incorporation). The result is in conformity with Reddy et al. (2005).

It is clear from the results that $75 \% \mathrm{~N}$ Urea $+25 \% \mathrm{~N}$ Poultry manure which applied in Band placement method $\left(\mathrm{N}_{2} \mathrm{M}_{2}\right)$ achieved higher values with regards to growth characters (plant height, number of branches/plant, dry matter accumulation/plant), yield, yield attributes( pods/plant, grain yield, straw yield and harvest index) and economics(gross returns, net returns \& B:C ratio). So that the treatment combination $\quad \mathrm{N}_{2} \mathrm{M}_{2} \quad(75 \% \mathrm{~N} \quad$ Urea+25\%N Poultry manure) applied in band placement is recommended. 


\section{References}

Almaz, M.G., Halim, R.A. and Martini, M.Y. (2017). Effect of Combined Application of Poultry Manure and Inorganic Fertiliser on Yield and Yield Components of Maize Intercropped with Soybean. Pertanika J. Trop. Agric., 40(1).

Azam Shah, S., Mahmood Shah, S., Mohammad, W., Shafi, M. and Nawaz, H.(2012). N uptake and yield of wheat as influenced by integrated use of organic and mineral nitrogen. Int. J. Plant Prod., 3(3): 45-56.

Din, J., A. Rashid and A.I. Ahmed. 1999. Diagnosis and correction of phosphorus deficiency in chickpea grown in rainfed calcareous soils of Pakistan. J. Indian Soil Sci. 477 (3): 504 - 509.

Gomez A A, Gomez KA (1984) Statistical Procedures for Agricultural Research, John Wiley and Sons, Ink., New York.

Grewal, Harbans Singh, Kolar, J. S. and Singh, Dalip (1994). Effect of potassium and nitrogen on growth and yield of soybean (Glycine max L. merr.) J. Potassium Res., 10(2) : 173-174.

Harmoney, K.R. and Thompson, C.A., (2005). Fertilizer rate and placement alters triticale forage yield and quality. Forage and grazinglands, 3(1).

Mamia, A., Amin, A.K.M.R., Roy, T.S. and Faruk, G.M., (2018). Influence of Inorganic and Organic Fertilizers on Growth and Yield of Soybean. Bangladesh Agronomy Journal, 21(1): 77-81.
Nettles, V.F., (1940). Some effective methods of applying fertilizer. In Proceedings of the Florida State Horticultural Society (Vol. 53, pp. 202-205).

Reddy, S., Shivaraj, B and Reddy, V.C. (2005). Effect of poultry manure, sewage sludge and urban garbage compost on yield, quality and economics of groundnut (Arachis hypogaea L.). Journal of Oilseeds Research. 22 (2): 245-248.

Shaheen, A., Tariq, R. and Khaliq, A., 2017. Comparative and interactive effects of organic and inorganic amendments on soybean growth, yield and selected soil properties. Asian. J. Agric. \& Biol., 5 : 60-69.

Shahzad, M.A., Shah, S.H. and Nazar, M.S., 2003. Growth and yield response of brassica cultivars to fertilizer application methods under saline field conditions. Journal of Agricultural Research (Pakistan).

Timmons, D.R., R.E. Burwell and R.F. Holt. 1973. Nitrogen and phosphorus losses in surface runoff from Agricultural land as influenced by placement of broad cost fertilizer. Water Resource Res. 9: 658-667.

Tisdale, G.L. and Nelson, W.L. (1975). Soil fertility and fertilizer. The McMillan Company Collier. McMillan Ltd., London, pp. 71-73.

Touchton, J.T. and Rickerl, D.H. (1986). Soybean Growth and Yield Responses to Starter Fertilizers. SOIL. SCI. SOC. AM. J., 50(1): 234-237.

\section{How to cite this article:}

Bala Manikanta, I., Jamkhogin Lhungdim, K. Nandini Devi, N. Surbala Devi and Gopimohan Singh, N. 2020. Influence of Nitrogen Sources and Application Methods on Growth and Yield of Soybean [Glycine max (L.) Merrill]. Int.J.Curr.Microbiol.App.Sci. 9(10): 618-624. doi: https://doi.org/10.20546/ijcmas.2020.910.073 